УДК 343.6

DOI https://doi.org/10.32849/2663-5313/2019.5.49

\title{
Владислав Чігер,
}

студент міжнародно-правового факультету

Національного юридичного університету імені Ярослава Мудрого

\section{КРИМІНАЛЬНА ВІДПОВІДАЛЬНІСТЬ ЗА ТОРГІВЛЮ ЛЮДЬМИ}

У статті розглядаються проблемні питанням, пов'язані з протидією торгівлі людьми. Наголошується на важлиості ивого питання на міжнародному та національному рівнях. Значну увагу приділено питанню нормативно-правового регулювання «торгівлі людьми». Указується на особливості кримінально-правової кваліфікацї̈ торгівлі людьми в Україні. Висловлюються пропозииї щодо вдосконалення чинного законодавства.

Ключові слова: торгівля людьми, проблема торгівлі людьми, кримінальне право, міжнародне співробітництво, злочин, експлуатація людини.

Постановка проблеми. Проблема торгівлі людьми вважається рабством 21-го століття. Його часто називають також «рабством наших днів», з огляду на те що в обох випадках людина розглядається лише як знаряддя або інструмент. Жертвами торгівлі людьми стають ті наші співвітчизники, які бажають за всяку ціну уникнути важких умов життя й із цією метою часто необачно погоджуються залишити батьківщину, наївно вірячи порожнім обіцянкам про швидке підвищення рівня своїх доходів. У результаті, багато хто 3 них потрапляє у важкі ситуації, стає жертвами безжалісної фізичної й моральної експлуатації, змушені виконувати важку, неоплачувану роботу вище своїх сил, а також зазнає побиття, погроз і принижень.

Проблема торгівлі людьми стала предметом занепокоєння для всього цивілізованого людства. Незважаючи на те що все більше країн об'єднує свої зусилля в боротьбі із цим явищем, сучасне рабство продовжує бути суворою дійсністю наших днів. Хоча сьогодні немає точних підрахунків, з різних джерел випливає, що у світі жертвами торгівлі людьми щорічно стає від двох з половиною до чотирьох мільйонів осіб. За різними підрахунками, щорічний прибуток, отриманий злочинцями від торгівлі людьми, вимірюється мільярдами доларів США.

Натепер такі злочини, як торгівля людьми та інші прояви експлуатації, не знають кордонів і мають місце як у багатих, так і в бідних країнах, завдаючи своїм жертвам настільки важких фізичних, психологічних або економічних збитків, що їх реабілітація та повернення в суспільство як повноправних членів вимагають додаткових зусиль і часу.

Проблему протидії торгівлі людьми детально розглядають іноземні науковці, зокрема А. Ароновіц, Г. Тойєрманн, Е. Тюрюканова. Ї̈̈ висвітлено також у матеріалах міжнародних наукових семінарів, методичних посібниках державних інституцій і міжнародних організацій ОБСЕ, МОП тощо. Серед вітчизняних науковців це питання досліджували такі вчені, як К. Левченко, А. Орлеан, Б Лизогуб, І. Лукашука, Є. Ляхова, А. Наумова, В. Панова, Ю. Решетова й інші.

Мета статті полягає в дослідження особливостей кримінально-правової кваліфікації торгівлі людьми за кримінальним законодавством України.

Виклад основного матеріалу. Проблема торгівлі людьми в минулому неодноразово привертала увагу міжнародної спільноти й окремих держав. Законодавство про заходи щодо протидії торгівлі людьми представлено низкою міжнародних конвенцій і декларацій, спрямованих на об'єднання зусиль усіх держав на боротьбу з торгівлею людьми, рабством і його проявами. $\mathrm{У}$ фокусі таких документів були передусім жінки і діти, які часто стають об'єктами насильства й торгівлі людьми в тому числі з метою сексуальної експлуатації.

3 метою підвищення ефективності й результативності розкриття кримінальних правопорушень і притягнення до відповідальності винних у них осіб, варто детально проаналізувати законодавство, зокрема норми Кримінального кодексу (далі - КК) України.

Нині єдиною статтею, що передбачає покарання за кримінальні правопорушення торгівлю людьми - або іншу незаконну угоду щодо людини, є стаття 149 КК України.

Уперше кримінальну відповідальність за торгівлю людьми встановлено Законом Укра- 
їни від 24 березня 1998 року № 210/98 ВР, згідно з яким КК України доповнено статтею 124-1 «Торгівля людьми». За роки дії цієї норми її редакція змінювалася чотири рази, що само по собі створює труднощі під час її застосування на практиці.

Чинна в Україні нормативна база протидії торгівлі людьми, що складається з національного й міжнародного законодавства, потребує доповнення й уточнення, хоча загалом придатна для створення дієвого механізму протидії торгівлі людьми.

Відповідно до національного кримінального законодавства, цей злочин, згідно з ч. 1 ст. 149 КК України, являє собою вербування, переміщення, переховування, передачу або одержання людини, вчинені з метою експлуатації, з використанням обману, шантажу чи вразливого стану особи [1].

Кваліфікуючими обставинами в досліджуваному складі злочину є торгівля неповнолітніми, щодо кількох осіб, або повторно, або за попередньою змовою групою осіб, або службовою особою з використанням службового становища, або особою, від якої потерпілий був у матеріальній чи іншій залежності, або поєднані з насильством, яке не є небезпечним для життя чи здоров'я потерпілого чи його близьких, або з погрозою застосування такого насильства. Особливо кваліфікуючими обставинами є дії, вчинені щодо малолітнього, або організованою групою, або поєднані $з$ насильством, небезпечним для життя чи здоров’я потерпілого або його близьких, або з погрозою застосування такого насильства, або якщо вони спричинили тяжкі наслідки [1].

Законодавцем у диспозиції ст. 149 КК України застосовано термін «торгівля людьми», однак чинні норми кримінального права не містять чіткого визначення наведеного терміна. У судовій практиці та кримінальноправовій характеристиці торгівлі людьми, яка здійснена науковцями, поняття торгівлі людьми ототожнюється 3 купівлею-продажем людини як товару.

Непоодинокими є випадки, коли торгівлю людьми суди тлумачать як купівлюпродаж у цивільно-правовому контексті й фактично застосовують цивільно-правовий аналіз правочину купівлі-продажу до цих правовідносин, указуючи на наявність істотних умов і зобов'язань, які є визначальними в цивільно-правових відносинах. На практиці під час учинення злочину, за ст. 149 КК України, купівля-продаж у класичному цивільно-правовому значенні може не мати місця, але визначальним для вирішення справ про торгівлю людьми є факт передачі людини (чи управління людиною), незалежно від виникнення інших зобов'язань, властивих правочину купівлі-продажу, таких як ціна, наявність і форма оплати за передачу людини (боргова кабала передбачає оплату шляхом відпрацювання).

Об'єктом торгівлі людьми законодавець уважає свободу (волю), честь або гідність особи. Обов'язковою ознакою складу злочину, передбаченого ст. 149 КК України, є предмет злочину.

Обов'язковою ознакою складу злочину, передбаченого ст. 149 КК України, є предмет злочину. Предметом цього злочину є людина. Ні труп людини, ні їі органи (тканини) не $є$ предметом зазначеного злочину. Тому намагання вчинити діяння, передбачені ст. 149 КК України, стосовно мертвої людини може бути кваліфіковано лише як замах на торгівлю людьми (у разі неусвідомлення винними особами того, що людина, яка є предметом угоди, померла). Учинення жінкою будь-яких незаконних угод щодо своєї ненародженої дитини під час вагітності не утворює складу закінченого злочину та може кваліфікуватися лише як замах на торгівлю людьми [2, ст. 20].

Об'єктивна сторона складу злочину є чи не найважливішим для практичної діяльності елементом складу злочину. Шляхом дослідження об'єктивної сторони робиться висновок про зміст інших елементів складу злочину, а будь-який висновок у кримінальній справі може бути здійснений виключно за матеріальними слідами, які залишає після себе злочин у реальній дійсності. У правозастосовній практиці працівниками правоохоронних органів передусім установлюється об'єктивна сторона складу злочину [3, ст. 116]. Цей злочин може мати такі форми: 1) торгівля людьми; 2) здійснення іншої незаконної угоди, об'єктом якої є людина; 3) вербування; 4) переміщення; 5) переховування; 6) передача; 7) одержання людини.

3 огляду на суспільну небезпеку такого злочину, як торгівля людьми (купівля-продаж), достатньо встановити факт домовленості на продаж людини на певних умовах i сам факт передачі людини (чи управління людиною). Чинне законодавство не вимагає обов'язкової умови для кваліфікації злочину за ст. 149 КК України - установлення одномоментної передачі (сплати) коштів за товарлюдину, оскільки купівля-продаж може відбуватися з відстрочкою платежу чи злочинці можуть домовитись про сплату коштів від продажу людини впродовж певного часу, за який потерпіла особа зможе відпрацювати частину коштів.

Торгівля людьми незалежно від форми їі зовнішнього прояву може бути вчинена лише з прямим умислом. Наявність згоди потерпі- 
лого свідчить про відсутність прямого умислу на вчинення торгівлі людьми, а отже, і про відсутність складу злочину загалом.

Певні складнощі виникають під час вирішення питання щодо учасників - суб'єктів складу злочину, передбаченого ст. 149 КК України. Ідеться про те, купівля-продаж людини можлива тільки між вербувальником та особою, яка буде здійснювати експлуатацію, або може мати місце торгівля людьми й між іншими суб'єктами, оскільки в багатьох випадках суди стикаються з тим, що в кримінальних правопорушеннях був відсутній покупець.

У такому випадку, коли вербувальник у подальшому сам здійснює експлуатацію потерпілої особи, кримінальна відповідальність не виключається та повинна наставати за ст. 149 КК України за вербування, переміщення, передачу, переховування, одержання людини, вчинені з метою експлуатації, з використанням одного зі способів впливу.

Основними проблемами запобігання цьому виду злочину й виявлення його є те, що не всі жертви можуть або бажають звернутися за захистом своїх прав. Багато жертв просто не знають, куди звернутися за допомогою. Дуже часто перешкодою слугує й така обставина, що правоохоронні органи зарубіжних держав відмовляються співпрацювати з правоохоронними органами України.

Реальні цифри жертв работоргівлі на порядок вищі за ті, що надаються міжнародними організаціями. Для боротьби з торгівлею людей в Україні, а також у всьому світі необхідна співпраця держав у цій сфері, удосконалення законодавчої бази, розвиток потенціалу системи кримінального правосуддя в Україні, зокрема міліції, слідчих, прокурорів і судових органів. Так само необхідна боротьба держави 3 такими соціальними явищами, як бідність і неосвіченість. Держава повинна надавати соціальний захист, психологічну та фінансову допомогу постраждалим, а також надавати робочі місця для населення країни.

Найдієвіший спосіб запобігання торгівлі людьми - це створення урядами широких потоків легальної й законної міграції. Залучення більшості мігрантів до використання офіційних каналів допоможе урядам точніше виявити, ізолювати і припинити використання незаконних методів. Крім того, легальні потоки міграції можуть мати позитивні наслідки для суспільства загалом.

\section{Висновки}

Отже, норма ст. 149 КК України потребує вдосконалення, оскільки вона не дає повноцінного розуміння кримінального явища, яке являе собою торгівлю людьми. Торгівля людьми - це неприпустиме суспільне явище, якому необхідно рішуче протидіяти. Протидія цьому явищу вимагає вироблення ефективних методів як на державних, так і на міжнародних рівнях. Тому потрібно провести ретельнішу імплементацію норм міжнародного права до законодавства України, у тому числі імплементувати норми міжнародних конвенцій щодо означеної проблеми. Саме це дасть змогу більш раціонально застосовувати чинне законодавство для протидії людьми.

3 огляду на викладене, стає очевидним, що в Україні є досить великий спектр проблем, пов'язаних із протидією та запобіганням торгівлі людьми або іншими незаконними угодами щодо людини, починаючи з виявлення такого протиправного діяння. Сформована в Україні нормативно-правова база для боротьби із цим видом транснаціональної злочинності потребує подальшого вдосконалення відповідно до міжнародних вимог і стандартів забезпечення прав кожної особи й контролю за виконанням законодавства щодо їх охорони. Адже неправильна кваліфікація кримінальнокараних діянь може призвести до почастішання випадків порушення прав і свобод громадян. Злочини, пов'язані з торгівлею людьми, залишаються у сфері наукових інтересів автора й вимагають подальшого дослідження.

\section{Список використаних джерел:}

1. Кримінальний кодекс України: Закон України від 05.04.2001 № 2341-III / Верховна Рада України. URL: http://zakon0.rada.gov.ua/laws/ show/2341-14

2. Никифоряк Л.П., Орлеан А.М. Аналіз судової практики з питань застосування законодавства України щодо протидії торгівлі людьми. Київ: Фенікс, 2018. 88 c. URL: http://iom.org.ua/sites/ default/files/analysis of judicial practice.pdf.

3. Україна як країна призначення для торгівлі людьми. Матеріали для практичного використання працівниками прикордонної служби, правоохоронних органів та суддями / М.О. Васильєва, В.В. Касько, А.М. Орлеан, О.В. Пустова. Київ: Фенікс, 2012. 120 c. URL: http://iom.org.ua/sites/ default/files/krayina_pryzn4_layout_1.pdf. 
В статье рассматриваются проблемнье вопросы, связанные с противодействием торговле людьми. Отмечается важность данного вопроса на международном и начиональном уровнях. Значительное внимание уделено вопросу нормативно-правового регулирования «торговли людьми». Указывается на особенности уголовно-правовой квалификаиии торговли людьми в Украине. Вносятся предложения по совершенствованию действующего законодательства.

Ключевые слова: торговля людьми, проблема торговли людьми, уголовное право, международное сотрудничество, преступление, эксплуатация человека.

The article deals with problematic issues related to combating human trafficking. The importance of this issue at the international and national level is noted. Considerable attention is paid to the issue of the regulatory framework for "trafficking in persons". Indicates the features of the criminal law qualification of human trafficking in Ukraine. There are suggestions to improve the current legislation.

Key words: human trafficking, human trafficking problem, criminal law, international cooperation, crime, human exploitation. 